\title{
Senam Lansia dan Tingkat Stres pada Lansia di Dusun Polaman Argorejo Kecamatan Sedayu 2 Kabupaten Bantul Yogyakarta
}

\author{
Raden Jaka $\mathrm{S}^{1}$, Tri Prabowo², Wahyu Dewi $\mathrm{S}^{3}$ \\ ${ }^{1,3}$ Sekolah Tinggi Ilmu Kesehatan Alma Ata Yogyakarta \\ Jalan Ringroad Barat Daya No 1 Tamantirto, Kasihan, Bantul, Yogyakarta \\ ${ }^{2}$ Program Studi Keperawatan Politeknik Kesehatan Kementrian Kesehatan Yogyakarta \\ Jalan Tata Bumi No. 3, Sleman, Daerah Istimewa Yogyakarta
}

\begin{abstract}
Abstrak
Aktifitas fisik pada lansia dapat menjadi sebuah mekanisme untuk meningkatkan kesejahteraan yang berkaitan dengan stres yang dihadapi lansia. Akan tetapi lansia masih jarang terlibat dalam aktifitas fisik tersebut. Tujuan dari penelitian ini adalah untuk mengetahui hubungan senam lansia dengan tingkat stres pada lansia di Dusun Polaman Argorejo, Kecamatan Sedayu 2, Kabupaten Bantul Yogyakarta. Penelitian ini merupakan penelitian analitik kuantitatif dengan rancangan cross sectional. Populasi dalam penelitiana ini adalah lansia yang tinggal di Dusun Polaman yang berjumlah 90 orang. Pengambilan sampel dalam penelitian ini menggunakan teknik total sampling yaitu mengambil semua anggota populasi menjadi sampel yang sesuai dengan kriteria inklusi dan eksklusi yang tinggal di Dusun Polaman (90 orang). Data yang telah dikumpulkan kemudian dianalisis menggunakan uji statistik Chi-Square. Hasil penelitian menunjukan lansia yang aktif mengikuti senam lansia dan tidak mengalami stres sebanyak 16 responden (76,2\%), lansia yang aktif mengikuti senam dan mengalami stres sebanyak 5 responden (23,8\%), ada hubungan antara senam lansia dengan tingkat stress dengan nilai $p=0,000$, dan kekuatan hubungan sedang dengan nilai koefisen korelasi 0,553. Kesimpulan ada hubungan antara senam lansia dengan tingkat stres pada lansia di Dusun Polaman Argorejo Bantul Yogyakarta.
\end{abstract}

Kata Kunci: senam lansia, stres, lansia

\section{Gymnastics and Level Stress of Elderly in Polaman Village Argorejo Sedayu 2 Subdistrict Bantul District, Yogyakarta}

\begin{abstract}
Physical activity of elderly can be a mechanism of dealing with stress. However, older people are rarely engage in the physical activity. The purpose of this study was to know the relationship between elderly gymnastics and level stress in village of Polaman Argorejo, District of Bantul Yogyakarta. This study was an analytic quantitative research with cross sectional design. The population in this study was elderly that lived in Polaman village which totaled 90 respondents. Technique sampling used was total sampling resulted on 90 respondents. The analysis used was chi-square. Results showed that elderly who actively participated in gymnastic and not stress was 16 respondents (76,2\%), while elderly who actively participated in gymnastic and stress was 5 respondents (23,8\%), there was a significant relationship between gymnastic and the level of elderly stress with value of $p=0,000$. In conclusion, there was a significant relationship between gymnastics for the elderly and stress level on elderly in Polaman village Argorejo Bantul Yogyakarta.
\end{abstract}

Keywords: gymnastics elderly, stress, elderly

Info Artikel:

Artikel dikirim pada 11 Juni 2015

Artikel diterima pada 13 Juni 2015 


\section{PENDAHULUAN}

Pertumbuhan manusia menuju lanjut usia merupakan bagian dari tahap pertumbuhan hidup manusia yang tidak bisa dihindari. Sehat meski memasuki usia senja adalah harapan semua orang. Berbagai upaya dilakukan untuk menjaga tubuh tetap sehat dan terhindar dari segala penyakit. Lansia merupakan seorang individu laki-laki maupun perempuan yang berumur antara 60-69 tahun(1).

Jumlah lanjut usia diseluruh dunia saat ini diperkirakan ada 500 juta dengan usia rata-rata 60 tahun dan diperkirakan pada tahun 2025 akan mencapai 1,2 milyar. Pertambahan lanjut usia di negara maju seperti Amarika Serikat mencapai 1.000 orang perhari pada tahun 1985 sehingga istilah baby-boom pada masa lalu berganti menjadi ledakan penduduk lanjut usia(2).

Perkembangan penduduk lanjut usia di Indonesia menarik diamati, dari tahun ke tahun jumlahnya cendrung meningkat. Berdasarkan hasil sensus penduduk 2010 secara umum jumlah penduduk lanjut usia di Indonesia sebanyak 18,04 juta orang atau 7,59 persen dari keseluruhan penduduk indonesia. Jumlah penduduk lansia perempuan $(9,75$ juta orang) lebih banyak dari jumlah penduduk lansia laki-laki $(8,29$ juta orang). Sebaranya jauh lebih banyak di daerah pedesaan (10,36 juta orang) dibandingkan di daerah perkotaan (7,69 juta orang). Penduduk lansia terbanyak terdapat di provinsi DI Yogyakarta dengan jumlah lansia sebanyak 448.223 orang atau 12,96 persen dari keseluruhan penduduk, yang terdiri dari penduduk lansia perempuan 249.784 orang dan penduduk lansia laki-laki sebanyak 198.439 orang(2). Pada tahun 2020-2025, Indonesia akan menduduki peringkat negara dengan struktur dan jumlah penduduk lanjut usia setelah RRC, India, dan Amerika Serikat, dengan umur harapan hidup diatas 70 tahun(1).

Lanjut usia sering kali dipersepsikan secara negatif, dianggap sebagai beban keluarga dan masyarakat sekitarnya. Kenyataan ini mendorong semakin berkembangnya anggapan bahwa menjadi tua itu identik dengan semakin banyaknya masalah kesehatan yang dialami oleh lanjut usia. Persepsi negatif seperti itu tentu saja tidak semuanya benar, karena ada pula lanjut usia yang berperan aktif tidak saja dalam keluarganya, tetapi juga dalam masyarakat sekitarnya. Kurangnya perhatian terhadap kelompok lanjut usia, dapat menimbulkan permasalahan yang kompleks terhadap lanjut usia tersebut, mengingat bahwa kesehatan merupakan aspek sangat penting yang perlu diperhatikan pada kehidupan lanjut usia(3).
Dalam perjalanan lanjut usia mengalami perubahan pada sistem tubuhnya. Perubahan tersebut meliputi perubahan fisiologis, perubahan fungsional, perubahan kognitif, dan perubahan psikososial ${ }^{4}$. Lebih lanjut menjelaskan bahwa perubahan psikososial selama proses penuaan akan melibatkan proses transisi kehidupan dan kehilangan. Semakin panjang usia seseorang, maka akan semakin banyak pula transisi dan kehilangan yang dihadapi. Hal ini dapat menimbulkan stres pada lanjut usia dan adanya kemungkinan resiko bunuh diri(4).

Stres merupakan respon tubuh yang bersifat tidak spesifik terhadap setiap tuntutan atau beban atasnya. Berdasarkan pengertian tersebut dapat dikatan stres apabila seseorang mengalami beban atau tugas yang berat tetapi orang tersebut tidak dapat mengatasi tugas yang dibebankan, maka tubuh akan berespon dengan tidak mampu terhadap tugas tersebut, sehingga orang tersebut dapat mengalami stres. Sebalikanya apabila seseorang yang dengan beban tugas yang berat tetapi mengatasi beban tersebut dengan respon tubuh yang baik, maka orang itu tidak mengalami stres(5).

Penelitian menunjukan tingkat stres yang tinggi pada lanjut usia, dengan $21,25 \%$ menunjukan keluhan berat dan $18,75 \%$ menunjukan keluhan sedang. Sedangkan faktor-faktor yang menyebabkan stres pada lansia diantaranya perubahan dalam aktifitas sehari-hari, perubahan dalam perkumpulan keluarga, kematian pasangan, kematian anggota keluarga, dan perubahan dalam kuantitas olahraga serta perubahan dalam bekerja(6).

Berdasarkan hasil penelitian yang dijelaskan di atas dapat dilihat bahwa salah satu masalah yang sering dihadapi oleh lansia adalah stres akibat dari terjadinya perubahan-perubahan alamiah pada diri lansia. Lansia yang tinggal dirumah maupun lansia yang tinggal di panti juga beresiko untuk mengalami stres, baik berat, sedang, maupun ringan. Untuk mengatasi hal tersebut maka lansia perlu cara untuk mengatasi stres.

Aktifitas olahraga merupakan salah satu mekanisme untuk menghadapi stres pada lansia. Aktifitas olahraga akan membantu tubuh tetap bugar dan segar karena melatih tulang tetap kuat, mendorong jantung bekerja optimal, dan membantu menghilangkan radikal bebas yang ada didalam tubuh. Jenis olahraga yang paling tepat bagi lansia adalah latihan senam yang disertai latihan-latihan kekuatan ditambah gerakan perimbagan dan peregangan(1).

Senam lansia termasuk senam aerobic low infact (menghindari gerakan loncat-loncat), intensitas ringan sampai sedang, bersifat menyeluruh dengan gerakan yang melibatkan sebagian besar otot tubuh. 
Manfaat gerakan-gerakan dalam senam lansia diharapkan dapat meningkatkan kekuatan dan ketahanan otot serta dapat mengurangi gangguan psikologis seperti stres pada lansia(1).

Adapun penelitian ini akan dilakukan di Dusun Polaman, Desa Argorejo, Kecamatan Sedayu 2, Kabupaten Bantul, Provinsi Daerah Istimewa Yogyakarta. Berdasarkan survei awal yang dilakukan peneliti di Desa Polaman didapatkan lansia sebanyak 90 orang. Selain melakukan observasi peneliti juga mewawancarai 3 orang lansia di Dusun Polaman untuk mengetahui gambaran tingkat stres. Hasil wawancara diperoleh 2 dari 3 orang lansia mengalami stres berat dengan menyatakan bahwa akan menyendiri dikamar apabila mengalami masalah dalam hidupnya dan lansia berikutnya mengalami stres ringan.

Berdasarkan latar belakang masalah yang telah dikemukakan di atas maka rumusan masalah yang diteliti adalah apakah ada hubungan senam lansia dengan tingkat stres pada lansia di Dusun Polaman Argorejo, Kecamatan Sedayu 2, Kabupaten Bantul, Yogyakarta. Adapun tujuan dari penelitian ini adalah untuk mengetahui senam lansia di Dusun Polaman, untuk mengetahui tingkat stres lansia yang aktif dan tidak aktif mengikuti senam lansia di Dusun Polaman, dan Teridetifikasinya hubungan senam lansia dengan tingkat stres pada lansia yang tinggal di Dusun Polaman, Argorejo Yogyakarta.

\section{BAHAN DAN METODE}

Jenis penelitian ini adalah penelitian analitik kuantitatif dengan rancangan cross sectional. Populasi dalam penelitian ini adalah lansia yang tinggal di Dusun Polaman yang berjumlah 90 orang. Pengambilan sampel dalam penelitian ini menggunakan teknik total sampling yang berjumlah 90 orang. Instrumen senam lansia yang digunakan dalam penelitian ini berupa data sekunder keaktifan senam lansia dalam 1 bulan terakhir yaitu lansia aktif apabila mengikuti senam lansia 4 kali berturut-turut selama 4 minggu tanpa ada jeda tidak mengikuti senam lansia diberi skor 1 dan tidak aktif apabila tidak mengikuti senam lansia 4 kali berturut-turut atau ada jeda tidak mengikuti senam lansia diberikan skor 0 . Untuk mengukur tingkat stres yaitu menggunakan Depresion Anxiety Stres Scale (DASS) dari Livibond, SH dan Livibond, PF merupakan kuesioner yang digunakan untuk mengukur tingkat depresi, tingkat kecemasan, dan tingkat stres. Skala tersebut memberi nilai untuk setiap kondisi kehidupan sehari-hari yang menjadi sumber dan tanda-tanda stres. Alat ukur tersebut membagi persepsi responden yang mengalami peristiwa kehidupan tersebut menjadi tiga penilaian yaitu jawaban "sangat sesuai" skor 3 , jawaban Ordinal "sesuai" skor 2, dan jawaban "tidak sesuai" skor 1, apabila responden "sangat tidak sesuai" hal tersebut mendapatkan skor 0 . Uji validitas dan realibilitas tidak dilakukan oleh peniliti karena alat ukur yang dipakai sudah baku yaitu menggunakan Depresion Anxiety Stress Scale (DASS) dari Livibond, SH dan Livibond, PF yang telah dilakukan uji validitas dan realibilitas oleh Mastuti(7). Analisis data menggunakan analisis univariat dan bivariat dengan uji chi-square. Selain itu variabel independent penelitian ini yaitu senam lansia, sedangkan variabel dependent yaitu tingkat stres lansia.

\section{HASIL DAN BAHASAN}

Responden dalam penelitian ini adalah lansia yang tinggal di Dusun Polaman yang memenuhi standar kriteria. Secara lengkap karakteristik responden akan disajikan dalam Tabel 1.

Tabel 1. Distribusi Frekuensi Berdasarkan Karakteristik Responden di Dusun Polaman Argorejo Yogyakarta

\begin{tabular}{lcc}
\hline \multicolumn{1}{c}{ Karakteristik } & $\mathbf{f}$ & $\%$ \\
\hline $\begin{array}{l}\text { Jenis kelamin } \\
\text { Laki-laki }\end{array}$ & 41 & 45,6 \\
$\quad$ Perempuan & 49 & 54,4 \\
Usia & & \\
60-65 & 47 & 52,2 \\
$66-70$ & 30 & 33,3 \\
>70 & 13 & 14,4 \\
Pekerjaan & & \\
$\quad$ Dagang & 15 & 16,7 \\
Petani & 40 & 44,4 \\
Pensiunan & 6 & 6,7 \\
Tidak bekerja & 29 & 32,2 \\
Pendidikan & & \\
Tidak sekolah & 6 & 6,7 \\
SD & 46 & 51,1 \\
SMP & 24 & 26,7 \\
SMA & 8 & 8,9 \\
PT & 6 & 6,7 \\
Total & 90 & 100,0 \\
\hline
\end{tabular}

Sumber: Data Primer Tahun 2015

Berdasarkan Tabel 1 dapat dilihat bahwa reponden dengan karakteristik jenis kelamin perempuan lebih banyak dibandingkan dengan responden laki-laki yaitu sebesar 49 responden $(54,4 \%)$. Hal ini sesuai dengan salah satu teori bahwa angka harapan hidup pada perempuan lebih tinggi dari angka harapan hidup laki-laki sehingga banyak lansia yang berjenis kelamin perempuan.

Pada karakterisrik usia, responden dengan usia 60-65 tahun lebih banyak dibandingakan dengan 
responden yang berusia lebih dari 65 tahun yaitu sebanyak 47 responden $(52,2 \%)$, sedangkan pada karakteristik pendidikan dan pekerjaan, mayoritas responden yang tinggal di Dusun Polaman bekerja sebagi petani yaitu sebanyak 46 responden $(51,1 \%)$ dengan pendidikan terbanyak pada sekolah Dasar yang berjumlah 40 responden $(44,4)$. Sampel yang diperoleh adalah 90 responden yang berusia $\geq 60$ tahun karena senam lansia ditunjukan pada lansia. Seseorang disebut sebagai lansia karena telah berusia lebih dari 60 tahun ke atas.

Pada distribusi tingkat pendidikan Iansia menunjukan sebagian besar lansia memiliki tingkat pendidikan rendah yaitu SD yang berjumlah 46 responden $(51,1 \%)$ sedangkan lansia yang sampai pendidikan perguruan tinggi hanya 6 responden $(6,7 \%)$. Data menjelaskan bahwa banyaknya lansia yang tidak bersekolah dan berpendidikan rendah disebabkan karena pada jaman dahulu pada saat lansia berada pada usia sekolah, sekolah masih jarang ada dan hanya orang tertentu saja yang bisa bersekolah(8).

Kegiatan senam lansia di wilayah Dusun Polaman tidak diikuti oleh lansia yang berusia lebih dari 70 tahun karena lansia pada usia ini banyak yang sudah tidak bisa mengikuti kegiatan seperti senam lansia, ada juga yang tidak diijinkan oleh keluarga karena takut terjadi hal-hal yang tidak diinginkan.

Salah satu teori menjelaskan, semakin lanjut usia seseorang terjadi beberapa proses perubahan dimana kepekaan bertambah atau batas kemampuan beradaptasi menjadi berkurang yang sering dikenal dengan geriatric giant, dimana lansia akan mengalami masalah yaitu gangguan imobilisasi, instabilitas (mudah jatuh), gangguan intelektualitas (demensia), isolasi (depresi), imunodefisensi, konstipasi, serta gangguan pada penglihatan, pendengaran, pengecapan, penciuman, dan komunikasi(9).

Tabel 2. Distribusi Frekuensi Responden Berdasarkan Keaktifan Mengikuti Senam Lansia di DusunPolaman Argorejo Yogyakarta

\begin{tabular}{lcc}
\hline \multicolumn{1}{c}{ Keaktifan } & f & $\%$ \\
\hline Aktif & 21 & 23,3 \\
Tidak aktif & 69 & 76,7 \\
Total & 90 & 100,0 \\
\hline
\end{tabular}

Sumber: Data Primer Tahun 2015

Berdasarkan Tabel 2 dapat dilihat bahwa berdasarkan hasil penelitian di Dusun Polaman Argorejo dari 90 responden yang diteliti, responden yang tidak aktif mengikuti senam lansia lebih banyak yaitu sebesar 69 responden $(76,7 \%)$, dibandingkan dengan responden yang aktif mengikuti senam lansia yaitu 21 responden $(23,3 \%)$.
Responden dengan katagori aktif mengikuti senam lansia adalah responden yang mengikuti senam lansia selama 4 kali berturut-turut selama 4 minggu tanpa ada jeda tidak mengikuti senam lansia, sedangkan lansia dengan katagoti tidak aktif adalah responden yang tidak mengikuti senam lansia senam lansia selama 4 kali berturut-turut dalam 4 minggu atau ada jeda tidak mengikuti senam lansia.

Hasil penelitian ini didukung oleh salah satu data yang menunjukan sebagian besar lansia yang di empat wilayah posyandu lansia tidak aktif mengikuti senam lansia. Ketidak aktifan responden dalam mengikuti senam dikarenakan responden yang bertempat tinggal jauh dari tempat pelaksanaan senam, kesibukan atau karena kondisi fisik yang tidak memungkinkan(10). Kondisi fisik atau kebugaran yang tidak baik juga dapat dipengaruhi oleh umur, jenis kelamin, kebiasaan merokok, dan latihan(11).

Penelitian ini juga menunjukan bahwa sebagian besar lansia yang tinggal di Dusun polaman mempunyai kesibukan bekerja sebagai petani dan pedagang, serta umur lebih dari 65 tahun mencapai $47,7 \%$ dari total populasi. Teori mengungkapkan, semakin lanjut usia seseorang terjadi beberapa proses perubahan dimana kepekaan bertambah atau batas kemampuan beradaptasi menjadi berkurang yang sering dikenal dengan geriatric giant, dimana lansia akan mengalami masalah yaitu gangguan imobilisasi, instabilitas (mudah jatuh), gangguan intelektualitas (demensia), isolasi (depresi), imunodefisensi, konstipasi, serta gangguan pada penglihatan, pendengaran, pengecapan, penciuman, dan komunikasi(9).

Tabel 3. Distribusi Frekuensi Responden Berdasarkan Tingkat Stres Pada Lansia di Dusun Polaman Argorejo Yogyakarta

\begin{tabular}{lcc}
\hline \multicolumn{1}{c}{ Tingkat Stres Lansia } & f & \% \\
\hline Tidak stres & 22 & 24,4 \\
Stres & 68 & 75,6 \\
Total & 90 & 100,0 \\
\hline
\end{tabular}

Sumber: Data Primer Tahun 2013

Pada Tabel 3 dapat dilihat bahwa berdasarkan hasil penelitian di Dusun Polaman Argorejo dari 90 responden yang diteliti, sebanyak 68 responden $(75,6 \%)$ mengalami stres sedangkan 22 responden lainnya $(24,4 \%)$ tidak mengalami stres.

Hasil penelitian ini didukung oleh data penelitian yang menunjukan lansia yang mengalami stres berat sebanyak $81,25 \%$ dan tingkat stres sedang sebanyak $18,75 \%$. Faktor-faktor yang menyebabkan stres pada lansia meliputi perubahan dalam aktifitas sehari-hari, 
kematian pasangan, kematian anggota keluarga, kualitas olahraga maupun rekreasi, serta perubahan dalam pekerjaan(12). Hal ini sesuai dengan salah satu teori bahwa gangguan yang sering terjadi pada usia lanjut adalah stres(5).

Stres sebagai stimulus yang menuntut dimana semakin tinggi atau besar tekanan yang dialami seseorang, maka semakin tinggi pula stres yang dialami(5). Stres yang dialami individu mempunyai beberapa tahapan diantaranya, stres tahap pertama, stres tahap kedua, stres tahap ketiga, stres tahap keempat, stres tahap kelima, dan stres tahap keenam(13). Salah satu teori mengatakan bahwa terjadinya stres karena stresor tersebut dirasakan dan dipersepsikan oleh individu sebagai ancaman sehingga menimbulkan kecemasan yang merupakan tanda umum dan awal dari gangguan kesehatan fisik dan psikologis(14). Stresor sendiri merupakan setiap keadaan atau peristiwa yang dapat menyebabkan perubahan dalam kehidupan seseorang (anak, remaja, dewasa,dan orang tua), sehingga individu tersebut terpaksa mengadakan adaptasi atau menanggulangi stresor yang timbul(13).

Tabel 4. Hubungan antara Senam Lansia dengan Tingkat Stres Lansia di Dusun Polaman Argorejo Yogyakarta

\begin{tabular}{lcccc}
\hline \multirow{2}{*}{$\begin{array}{c}\text { Senam } \\
\text { lansia }\end{array}$} & \multicolumn{2}{c}{ Tingkat stres } & \multirow{2}{*}{ Total } & p-value \\
\cline { 2 - 3 } & Tidak stres & Stres & & \\
\hline Aktif & 16 & 5 & 21 & 0,000 \\
& $76,2 \%$ & $23,8 \%$ & $100 \%$ & \\
Tidak aktif & 6 & 63 & 69 & \\
& $8,7 \%$ & $91,3 \%$ & $100 \%$ & \\
Total & 22 & 68 & 90 & \\
& $24,4 \%$ & $75,6 \%$ & $100 \%$ & \\
\hline
\end{tabular}

Sumber: Data Primer Tahun 2015

Berdasarkan Tabel 4 dapat dilihat bahwa dari responden yang aktif mengikuti senam lansia sebanyak 21 responden, 16 responden $(76,2 \%)$ diantaranya tidak mengalami stres, dan terdapat 5 responden $(23,8 \%)$ mengalami stres. Tabel tersebut juga menggambarkan bahwa dari 69 responden yang tidak aktif mengikuti senam lansia, 63 responden $(91,3 \%)$ mengalami stres, dan terdapat 22 responden $(8,7 \%)$ tidak mengalami stres.

Hasil analisis menggambarkan bahwa responden yang mengalami stres sebagian besar berasal dari responden yang tidak aktif mengikuti senam sedangkan responden yang tidak mengalami stres adalah responden yang aktif mengikuti senam lansia. Dari hasil tersebut dapat kita simpulkan bahwa semakin tidak aktif responden mengikuti senam lansia maka semakin tinggi pula tingkat stres yang dialami.
Hasil dari penelitian ini juga menggambarkan bahwa senam lansia dinyatakan berhubungan secara statistik dengan tingkat stres yang ditunjukan dengan uji ststistik chi-square diperoleh nilai $p$-value $0,000<0,05$, sehingga dapat disimpulka bahwa ada hubungan antara senam lansia dengan tingkat stres lansia, sedangkan keeratan hubungan terbilang sedang karena nilai koefisien kontingensi yaitu 0,553 . Hal ini dapat dipengaruhi oleh faktor-faktor lain yang dapat menurunkan stres seperti rekreasi, pengaturan nutrisi, istirahat dan tidur, pengaturan diet, serta dukungan sosial dan keluarga(5). Hasil penelitian ini didukung oleh data penelitian yang menunjukan hasil uji statitik menggunakan wilcoxon yaitu $p$-value $0,000(p<0,05)$, dan dapat ditarik kesimpulan bahwa ada pengaruh senam lansia terhadap penurunan tigkat stres(15). Penelitian ini juga didukung oleh data penelitian yang dengan hasil bahwa aktifitas fisik bisa mengurangi stres pada lansia dengan latihan di pusat kebugaran selama 60 menit selama 3 kali seminggu dalam 8 minggu(16).

Olahraga dalam hal ini senam lansia akan membantu tubuh tetap bugar dan segar karena melatih tulang tetap kuat, mendorong jantung bekerja optimal, dan peredaran darah lebih lancar. Selain itu olahraga teratur seperti senam akan memompa produksi Endorphin di otak yang akan memberi efek rasa senang dan nyaman. Salah satu manfaat dari hormon ini adalah mengendalikan stres dan meningkatkan kekebalan tubuh. Endorphin dalam tubuh bisa dipicu munculnya melalui berbagai kegiatan seperti dengan olahraga, pernapasan dalam, relaksasi, serta meditasi. Selain itu olahraga secara teratur memungkinkan tubuh untuk mengontrol situasi stres.

Senam lansia memberikan manfaat pada pembentukan kondisi mood yang lebih baik sehingga lansia yang rutin mengikuti kegiatan olahraga akan senantiasa dalam kondisi perasaan yang nyaman. Kondisi perasaan yang nyaman menjadikan individu dapat mengoptimalkan proses mental yang berfungsi dan berpengaruh pula pada kemampuan individu menghadapi setiap permasalahan yang dapat menimbulkan stres. Terlebih karena senam lansia dilakukan secara berkelompok dan biasanya diiringi dengan musik sehingga memberikan perasaan nyaman dan aman, serta tercipta suatu keceriaan dan kebersamaan sesama manusia lanjut usia. Oleh karena itu olahraga dalam hal ini senam lansia tetap memberikan peranan pada perubahan keadaan stres individu walaupun masih tetap ada faktorfaktor lain yang mempengaruhi. 


\section{SIMPULAN DAN SARAN}

Responden yang tinggal di Dusun polaman sebagian besar tidak aktif mengikuti senam lansia. Responden yang tidak aktif mengikuti senam lansia sebagian besar mengalami stres. Ada hubungan antara senam lansia dengan tingkat stres pada lansia yang ditunjukan dengan hasil uji statistik chi-square diperoleh nilai $p$-value $0,000<0,05$ dengan keeratan hubungan sedang serta arah korelasi positif yang menunjukan semakin tidak aktif responden mengikuti senam lansia maka semakin tinggi pula stres yang dialami.

Saran bagi institusi kesehatan diharapkan senantiasa dapat meningkatkan kegiatan-kegiatan rutin bagi lansia sehingga lansia bisa memanfaatkan kekosongan waktu yang ada dengan kegiatan bermanfaat dan tetap aktif walau usia lanjut, serta memberikan motivasi dan dukungan bagi lansia yang kurang aktif mengikuti kegiatan senam lansia.

\section{RUJUKAN}

1. Nugroho W. Keperawatan Gerontik dan Geriatrik. 3rd ed. Jakarta: EGC; 2008.

2. Bandyah S. Lanjut Usia dan Keperawatan Gerontik. Yogyakarta: Nuha medika; 2009.

3. Widuri H. Asuhan Keperawatan Pada Lanjut Usia Ditatanan Klinik. Yogyakarta: Fitramaya; 2010.

4. Perry, Potter. Fundamental of Nursing. 7th ed. Jakarta: Salemba Medika; 2009.

5. Hidayat A, Aziz A. Pengantar Konsep Dasar Keperawatan. 2nd ed. Jakarta: Salemba Medika; 2008.
6. Hidayat A, Aziz A. Riset Keperawatan dan Teknik Penulisan IImiah. 3rd ed. Jakarta: Salemba Medika; 2008.

7. Mastuti H. Hubungan Antara Religiusitas (Islam) dengan Kejadian Stres Pengguna Narkotika di Lembaga Pemasyarakatan Narkotika Kelas IIA Yogyakarta. Yogyakarta: Stikes Surya Global; 2009.

8. Rohmah. Hubungan senam Lansia Dengan Tingkat Stres di PSTW Dharma Bhakti. Surakarta: Politeknik Kesehatan Surakarta; 2012.

9. Darmojo. Geriatric (IImu Kesehatan Usia Lanjut). Jakarta: FKUI; 2011.

10. Nidya. Hubungan senam Lansia Dengan Fungsi Kognitif Pada Lansia di Emapat Posyandu Lansia Di Yogyakarta. Yogyakarta. Universitas Gajah Mada; 2011.

11. Afriwadi. Ilmu Kedokteran Olahraga. Jakarta: EGC; 2011.

12. Indriani Y. Tingkat Stres Lansia di Panti Werdha Pucang Gading Semarang. J Psikologi Undip. 2008;8(2).

13. Yosep I. Keperawatan Jiwa. Bandung: Refika Aditama; 2011.

14. Rasmun. Stres Koping dan Adaptasi. 1st ed. Jakarta: Sagung Seto; 2004.

15. Pratiwi E. Pengaruh Senam Lansia Terhadap Tingkat Stres Pada Lanjut Usia di PSTW Dharma Bakti. Surakarta: Fisioterpi Politeknik Kesehatan Surakarta; 2013.

16. Westerterp RK. Physical Activity and Oxidative Stress In The Elderly. European Journal of Applied Physiology. 2012;2(2). 